$\mathrm{Nr}$ 2(65), 2020, s. 123-131

https://doi.org/10.12797/Politeja.17.2020.65.09

\author{
Małgorzata GASZYŃSKA-MAGIERA (D) \\ Uniwersytet Warszawski \\ m.gaszynska-ma@uw.edu.pl
}

\title{
WARIANTY PAMIĘCI: \\ OBRAZ HISZPAŃSKIEJ WOJNY DOMOWEJ W POWIEŚCI MADAME ANTONIEGO LIBERY
}

ABSTRACT Variants of Memory: A Picture of Spanish Civil War in the Novel 'Madame' by Antoni Libera

The plot of the novel 'Madame' by Antoni Libera takes place in Poland in the sixties, in the times of the real socialism. The author, through the statements and behavior of the characters, presents two different attitudes towards the Spanish Civil War: first, revealed by the official propaganda, and the second popular among the opponents of the regime. Therefore, the memory of the Civil War, modified and appropriated by the followers of two different ideologies, has become a tool used by the author to contrast two opposing discourses about history of the $20^{\text {th }}$ century. In this way, the memory of the tragic events has come to the background, simply becoming part of the narrative strategy.

Keywords: contemporary Polish novel, Spanish Civil War, travelling memory, narrative strategies

Słowa kluczowe: polska powieść współczesna, hiszpańska wojna domowa, pamięć podróżująca, strategie narracyjne 
$\mathrm{P}$ owieść Antoniego Libery Madame odniosła niekwestionowany sukces. Historia młodzieńczego zauroczenia licealisty tajemniczą nauczycielką francuskiego, rozgrywająca się w latach 60 . XX wieku, podbiła serca polskich czytelników i zyskała uznanie krytyki. Historyczne tło powieści - polska rzeczywistość w czasach realnego socjalizmu - stanowiło prawdopodobnie dodatkowy atut dla zagranicznych odbiorców: została ona przetłumaczona, jak dotąd, na dwadzieścia jeden języków ${ }^{1}$. Wydana w 1998 roku, była późnym debiutem autora w świecie fikcji literackiej i jest, jak dotąd, jego jedyną powieścią. Libera był i pozostał przede wszystkim tłumaczem, głównie dramatów ${ }^{2}$.

Przedmiotem rozważań nie są jednak literackie walory utworu, lecz jedynie kilka jego fragmentów, nawiązujących do hiszpańskiej wojny domowej. Jest to temat, który w polskiej prozie współczesnej (mam tu na myśli okres po 1989 roku) pojawia się stosunkowo rzadko ${ }^{3}$. W strukturze omawianej powieści odgrywa on istotną rolę, ponieważ poświęcone mu rozdziały przywołują fragmenty biografii rodziców tytułowej Madame, które pozwalają zrozumieć motywy jej postępowania i wybory życiowe. Później ma to wpływ na zachowanie i losy głównego bohatera powieści, który jest narratorem historii.

Wojna domowa (1936-1939) jest wydarzeniem, którego pamięć do dziś elektryzuje hiszpańskie społeczeństwo, budząc wielkie kontrowersje i podsycając spory politycz$n e^{4}$. Można wręcz powiedzieć, że od dwóch dekad jest jednym z najważniejszych tematów debaty publicznej prowadzonej na Półwyspie Iberyjskim. Dystans czasowy powoduje, że uczestnicy i świadkowie tamtych wydarzeń nieuchronnie odchodzą, spór toczy się dziś już nie między nimi a ich potomkami, należącymi do pokoleń urodzonych po wojnie. A zatem pamięć o dramatycznych przejściach jest przez nich dziedziczona po rodzicach, dziadkach i innych krewnych, zapośredniczona przez ich relacje i wspomnienia 5 . Skala cierpień i pokoleniowy zasięg wojennej traumy, oddziaływanie

Angielski, białoruski, chiński, czeski, fiński, francuski, grecki, hebrajski, hiszpański, holenderski, kataloński, niemiecki, norweski, portugalski, rosyjski, słowacki, słoweński, szwedzki, turecki, węgierski, włoski.

2 Mam tu na myśli jedynie dokonania literackie; nie należy zapominać, że jest także reżyserem i krytykiem literackim. Libera przełożył m.in. dzieła Becketta, Szekspira, Sofoklesa.

3 Motyw hiszpańskiej wojny domowej bywał wykorzystywany w polskiej poezji i prozie w okresie PRL-u przede wszystkim w utworach o charakterze propagandowym, przywołujących hasta, które miaty umocnić historyczne podwaliny przekonania o walce klasowej (M. Bednarczuk, Obraz hiszpańskiej wojny domowej lat 1936-1939 w piśmiennictwie polskim, Torun 2008, s. 230). W utworach powstałych w Polsce po odwilży październikowej lub pisanych przez autorów emigracyjnych temat ten nie był ujmowany tak jednostronnie. W cytowanej monografii znajdzie Czytelnik obszerną analizę obecności tego motywu w polskiej literaturze (M. Bednarczuk, Obraz hiszpańskiej wojny domowej..., s. 225-299).

4 Można się było o tym przekonać, śledząc niedawną polemikę wokół ekshumacji szczątków generała Franco, pochowanego w Dolinie Poległych, i drastyczne sceny rozgrywające się w czasie jej trwania.

5 Jednocześnie wojna domowa była w Hiszpanii istotnym elementem kształcenia historycznego, jednak należy wziąć pod uwagę, że przekaz szkolny był w różnych okresach i w różnym stopniu zaburzany przez oficjalną ideologię, w konsekwencji pozbawiony obiektywizmu. Dopiero podręczniki napisane 
na kolejne generacje, które nie doświadczyły ich bezpośrednio, oraz wpływ na bieżące życie świadczący o niemożności uwolnienia się od tragicznej przeszłości każą postrzegać dziedzictwo hiszpańskiej wojny domowej w kategoriach postpamięci ${ }^{6}$.

Dla współczesnych Polaków w potocznym odbiorze hiszpańska wojna domowa jest jednym z historycznych epizodów poprzedzających wybuch II wojny światowej. Aktualne podręczniki do historii ograniczają się do zasygnalizowania, że takie wydarzenie miało miejsce, nie zagłębiając się w jego przyczyny i konsekwencje. Milczeniem pomijany jest także udział Polaków, członków Brygad Międzynarodowych. Zupełnie inaczej traktowała ten temat propaganda i historiografia czasów PRL-u, wpisując go w narrację o międzynarodowych ruchach komunistycznych. Znajdowało to wyraz w programach szkolnych i podręcznikach, co trafnie odzwierciedlają rozdziały Madame, które omówię poniżej.

Urodzony w 1949 roku Libera, sytuując zasadniczą część akcji w środowisku peerelowskiego liceum ogólnokształcącego, nawiązywał z pewnością do wspomnień $\mathrm{z}$ młodości. Portret szkoły jest, nawiasem mówiąc, zdumiewająco celny. Jednak wiedzę o hiszpańskiej wojnie domowej pisarz musiał czerpać z drugiej ręki. Nie jest ona w Polsce przedmiotem bezpośredniego przekazu międzypokoleniowego. Dla zdecydowanej większości Polaków stanowi raczej część historii ludzi zamieszkujących odległy kraj, z którymi w powszechnym odczuciu nie łączy ich wspólnota losów ani zbieżne interesy ${ }^{7}$.

Celem niniejszej analizy jest próba odpowiedzi na pytanie, co dzieje się z traumatyczną pamięcią, w momencie gdy zostaje przywołana w obcym dla siebie kontekście kulturowym. Rodzi zainteresowanie? Niepokoi? Wywołuje spory lub polemiki? Pozostaje niezauważona? Jest traktowana jako źródło poznawcze? Zmusza do refleksji? Za ramę teoretyczną rozważań wokół tych zagadnień posłuży zaproponowana przez Astrid Erll koncepcja pamięci wędrującej (travelling memory) ${ }^{8}$. Badaczka ta zwraca uwagę, że pamięć ma charakter dynamiczny, a jej formy i treści nabierają nowych znaczeń w zależności od zmieniających się uwarunkowań czasowych, społecznych i kulturowych ${ }^{9}$. Ruch jest immanentną cechą pamięci, jej podtrzymywanie jest wręcz od niego uzależnione. Nie jest też bezwarunkowo związana z kontekstem lokalnym, może bowiem podróżować - w dosłownym sensie. Inaczej mówiąc, może pojawić się w miejscu innym niż to, w którym rozgrywały się przywoływane z przeszłości wydarzenia, a dzieje się to dzięki nośnikom materialnym, takim jak np. pomniki, filmy, prasa i inne

po 1990 roku pokazują obraz wojny domowej na podstawie wiarygodnych źródłach i danych liczbowych (R. Valls Montés, Historiografía escolar española: siglos XIX-XXI, Madrid 2012).

6 Zob. M. Hirsch, Family Pictures. Maus, Mourning and Post-Memory, „Discourse” 1992/1993, vol. 15, nr 2, s. 3-29.

7 Zob. obszerną monografię: M. Nalewajko, Nieznani a bliscy. Historyczne i spoteczne uwarunkowania percepcji polskiej emigracji przetomu XX i XXI wieku w Hiszpanii, Warszawa 2012.

8 A. Erll, Travelling Memory, „Parallax” 2011, vol. 17, nr 4, s. 4-18. Termin wędrująca pamięć przyjmuję za polskim przekładem tego artykułu zawartym w tomie: Migracyjna pamięć, wspólnota, tożsamość, red. R. Sendyka, T. Sapota, R. Nycz, Warszawa 2016.

9 A. Erll, Travelling Memory, s. 11. 
artefakty. Ich cyrkulowanie w publicznym obiegu przyczynia się do rozpowszechniania różnych wariantów przeszłości ${ }^{10}$. Materialnymi nośnikami pamięci mogą być również książki. W omawianym przypadku opublikowanie dzieła literackiego, jakim jest Madame, pozwala niektórym wątkom hiszpańskiej pamięci przemieścić się z naturalnego dla siebie otoczenia rodzimego do obcego kontekstu polskiego.

Przyjrzyjmy się zatem, w jakich sytuacjach pojawiają się w powieści odwołania do wojny domowej i jaką funkcję pełnią. Są one głównym tematem dwóch rozdziatów. W tytule pierwszego z nich zostało wykorzystane rzucone przez Dolores Ibárruri hasło „No pasarán!”, które stało się najbardziej rozpoznawalnym zawołaniem strony republikańskiej.

Bohater powieści, znany ze swych talentów muzycznych, dostaje propozycję nie do odrzucenia od przewodniczącego szkolnego Związku Młodzieży Socjalistycznej: ma wziąć udział w akademii przygotowywanej z okazji trzydziestej rocznicy wybuchu hiszpańskiej wojny domowej na życzenie społeczności szkolnej, która rzekomo pragnie, by ta okazja zostata stosownie uczczona, i oczekuje [...] przygotowania imprezy ${ }^{11}$. Na program akademii składały się recytacje prozą i wierszem, a zadaniem bohatera miało być dobranie stosownej oprawy muzycznej.

Oficjalny przekaz o wojnie domowej prezentowany licealistom przedstawiał się następująco: $W$ wyniku rewolucji proletariackiej $w$ Rosji zmurszaty porzadek spoteczny zacofanej Hiszpanii zacząt się chwiać w posadach. Monarcha, Alfons XIII (jak najstuszniej noszacy to zniestawione imie)), w obliczu zwycięstwa lewicy „uciekt z kraju jak szczur” $i w$ roku trzydziestym pierwszym powstata Republika. Niestety, zamiast od razu, jak zalecat byt Lenin, przejść do najwyższej formy ustroju spotecznego, czyli do komunizmu, zastosowano pótśrodki, co rychto sięzemścito. „Hydra krwiożerczej reakcji podniosta plugawy teb" i $w$ roku trzydziestym trzecim zdobycze rewolucyjne zostaty anulowane. Robotnicy i chtopi zjednoczyli się wtedy we wspólnym froncie ludowym i w roku trzydziestym szóstym obalili prawice. Lecz zamiast dobic natychmiast "nikczemnego krwiopijcę", zlitowali się nad nim, co znowu byto fatalne. Puszczony wolno "gad" podnióst zaraz rebelię $i$ "rzucit sie wściekle do gardta mtodziutkiej Republice". Najgorsi drapieżcy świata - faszyści Niemiec i Wtoch - tylko na to czekali. "Węsząc za mordem i zyskiem”, pośpieszyli z pomoca straszliwemu Caudillo i po trzech latach walk zagryźli demokrację ${ }^{12}$. Nie dziwi zatem, że uroczystość ku czci obrońców Republiki była pełna stereotypów powtarzanych za obowiązującą propagandą. Akademię otwierał znany wiersz Władysława Broniewskiego No pasarán!, pretensjonalnie rozpisany na głosy narratora i chóru „bojowników”. Następującą w dalszej kolejności wygłaszaną patetycznym tonem opowieść o wojnie utkano z tekstów autentycznych przemówień, rezolucji i odezw. Jej styl był podporządkowany retorycznemu uniesieniu, dominował w niej pierwiastek emocjonalny, ze szkodą dla logiki. W efekcie okazała się ona pełna sprzeczności, z którymi niewprawny umyst, nieobeznany zwtaszcza z prawami dialektyki, zupetnie sobie nie radzit: Oto, choć Republika

\footnotetext{
10 Tamże, s. 12-13.

11 A. Libera, Madame, Kraków 2000, s. 158.

12 Tamże, s. 154
} 
byta demokratyczna, to jednak jej rzad - prawowity! - byt wsteczny: „burżuazyjny”. Ta okoliczność, z kolei, bynajmniej nie przeszkadzata najczarniejszej reakcji zawiąać natychmiast spisku przeciwko demokracji. Spisek ów, z jednej strony, byt dzietem „żatosnej mniejszości”, z drugiej, wzięty w nim udziat nieomal wszystkie sity „tego jeszcze na poty feudalnego państwa". Nie winno przeto dziwić, iż ów „waski margines" posiadat jednocześnie „mordercza, miażdżaca przewagę"13. Kulminacyjnym punktem programu był fragment przemówienia La Pasionarii do Dąbrowszczaków prezentowany przez piękność szkolną Lucylę Różogrodek, ubraną w czarną suknię, ozdobioną czerwonym goździkiem. Finał rozgrywał się na tle reprodukcji Guerniki Picassa, wyświetlanej z epidiaskopu, a całość zwieńczał inny wiersz Broniewskiego Czesś i dynamit. Jak komentuje sam narrator, w programie akademii spotkały się trzy charakterystyczne dla podobnych wydarzeń tamtych czasów elementy: komunistyczna tromtadracja, patos $i$ drętwa mowa ${ }^{14}$, znajdujące wyraz w utartych frazesach i przewidywalnych metaforach. Jednak domyślnym kontrapunktem była dla nich powszechnie czytywana przez młodych ludzi proza Hemingwaya, Sartre’a i Malraux, których wielbiono [...] bezkrytycznie i czczono niczym bogów $w^{15}$, co nie pozwalało do końca zohydzić i ośmieszyćc hiszpańskiej historii.

Z opisanej w książce akademii wyłania się obraz konfliktu na Półwyspie Iberyjskim nie tyle jako bratobójczej wojny, ile starcia światowych potęg z rodzącym się komunizmem. Miała to być raczej zbrojna krucjata światowego faszyzmu przeciw hiszpańskim masom, które los swego kraju wzięty we wtasne ręce. „Zbójeckie bandy "17 przysłane z zewnątrz były oczywistym dowodem na obcą interwencję. Ta wizja była zgodna z linią ideologiczną, która w okresie realnego socjalizmu obowiązywała w polskim systemie edukacyjnym. Epizody z najnowszej historii interpretowano zgodnie z logiką mającej rozgrywać się powszechnie walki mas o dobro wspólne, walki skierowanej przeciw klasom uprzywilejowanym i elementom reakcyjnym ${ }^{18}$. W takim ujęciu kontekst lokalny znikał z pola widzenia.

Tytuł kolejnego rozdziału ma, podobnie jak w przypadku poprzedniego, jawnie intertekstualny charakter: „Komu bije dzwon?”. Starszym czytelnikom nie trzeba przypominać, że słynna powieść Ernesta Hemingwaya stanowiła dla kilku pokoleń Polaków alternatywną wersję najnowszej historii Hiszpanii. Już sam tytuł rozdziału sugeruje zatem, że została w nim przedstawiona perspektywa inna niż ta przyjęta w narracji głoszonej przez komunistyczną propagandę. Jej wyrazicielem jest Konstanty, mentor głównego bohatera, co w oczach czytelnika czyni ją bardziej wiarygodną. Konstanty jest jednocześnie kimś w rodzaju porte-parole osób, które nie pogodziły się z panującym

13 Tamìe, s. 163.

14 Tamże, s. 167.

15 Tamże, s. 168.

16 Tamże, s. 167.

17 Tamże, s. 164.

18 Z. Osiński, Nauczanie historii w szkotach podstawowych w Polsce w latach 1944-1989. Uwarunkowania organizacyjne oraz ideologiczno-polityczne, Poznań 2010, s. 103-139; M. Żaryn, Polityka historyczna w edukacji w PRL, [w:] Polityka czy propaganda. PRL wobec historii, red. P. Skibiński, T. Wiścicki, Warszawa 2009, s. 125. 
w Polsce porządkiem politycznym. Tym samym nie akceptuje niczego, co głosi oficjalna propaganda. Chwilami wydaje się wręcz opętany obsesją: niemal każde wydarzenie z najnowszej historii interpretuje jako konsekwencję działalności politycznej lub militarnej Związku Radzieckiego. Jego opowieść o wojnie ma bezpośredni związek z losami ojca bohaterki powieści, który zaciągnął się do armii republikańskiej jako ochotnik, co zaważyło na dalszym życiu jego samego i jego rodziny.

W jego optyce hiszpańska wojna domowa była nie tyle zbrojną konfrontacją między zwolennikami legalnych rządów Republiki a faszystowskimi buntownikami pod wodzą generała Franco, ile raczej - a może nawet przede wszystkim - wojną ze Związkiem Sowieckim i jego wpływami. Dostrzegał tam tak naprawdę dwa fronty, nie jeden: że przeciw Republice walczy nie tylko Franco i jego poplecznicy ale i... Józef Stalin, i to znacznie skuteczniej, a zarazem - perfidniej ${ }^{19}$. Był to konstrukt intelektualny niełatwy do wytłumaczenia, jako że Sowieci wspierali przecież republikanów, wysyłając do Hiszpanii kadrę wojskową i broń. Ich domniemaną wrogość wobec hiszpańskiej lewicy Konstanty tłumaczył jej odległą od bolszewickiej linią ideologiczną, co miało w przyszłości grozić uniezależnieniem się od Związku Radzieckiego. Dlatego działalność agentów sowieckich po wyborczym zwycięstwie Frontu Ludowego w Hiszpanii w 1936 roku miała na celu wywołanie niepokojów społecznych: [...] gdy tylko zwyciężyt ów front ludowy, co jednak nie przyniosto oczekiwanych skutków, czerwone biesy natychmiast dolaty oliwy do ognia. Zaczety to diabelskie misterium podpalania, rozpasania i rzezi. Morderstwa polityczne, prowokacje, napady i niekończacy się strajk. Rozkręcać spirale gwattu, podsycać ogień anarchii, aby w jakimśmomencie, gdy zamroczenie zbiorowe osiagnie apogeum, chwycić wszystkich za gardto i rzucić na kolana. I od tej chwili już wtadać - niepodzielnie, bezwzględnie ${ }^{20}$. Gdyby przyjąć ten punkt widzenia, Sowieci musieliby się okazać rzeczywistymi odpowiedzialnymi za wybuch wojny domowej: Tak się zaczęta ta wojna. Oto prawdziwe jej tto. Gdyby nie pucz komunistów, gdyby nie Komintern, gdyby nie wypuszczenie mottochu na ulice, z pewnościa by do niej nie doszto ${ }^{21}$. Ponieważ Związek Radziecki nie miał dość siły militarnej, by podbić Hiszpanię i zaprowadzić tam reżim w sowieckim stylu, uznano, że korzystniej będzie pozwolić zwyciężyć faszystom: [...] rebelia frankistowska wprost spadata im z nieba. Zreszta, robili wszystko, aby ja sprowokować. A odkad wojna wybuchta i wtaczyli sie do niej Mussolini i Hitler, pozostawato już tylko tak zręcznie manewrować, by trwata jak najdtużej. A na koniec przyspieszyć wielki finat: ze wszech miar pożadany upadek Republi$k i^{22}$. Wreszcie, zdaniem Konstantego, na wojnie w Hiszpanii Sowieci po prostu zrobili świetny interes: Wiesz, ile Stalin wycisnąt w tym okresie z Hiszpanii? Sześćset milionów dolarów! Wztocie! Nie w żadnych papierkach ${ }^{23}$ - tłumaczył swemu młodemu słuchaczowi.

Lektura omawianego rozdziału nie pozostawia wątpliwości, że obraz wojny domowej był zniekształcany nie tylko przez oficjalną propagandę. Jej wizję głoszoną przez

\footnotetext{
19 A. Libera, Madame, s. 176.

20 Tamże, s. 177.

21 Tamże.

22 Tamże, s. 178.

23 Tamże.
} 
przeciwników komunistycznego reżimu równie trudno uznać za obiektywną, obie są dość odległe od prawdy historycznej ${ }^{24}$. Oczywiście, nie można zanegować, że na Półwyspie Iberyjskim w drugiej połowie lat 30. krzyżowały się interesy wielu państw, także Związek Radziecki walczył tam o poszerzenie swojej strefy wpływów, ale nie sposób przyjąć, że w pełni kontrolował sytuację i był głównym sprawcą, niemal demiurgiem, wszystkich rozgrywających się wydarzeń.

Nietrudno zauważyć, że w omawianej powieści zderzają się dwie różne narracje o hiszpańskiej wojnie domowej: jedna rozpowszechniana przez oficjalne kanały i media, zgodna z obowiązującą w PRL-u doktryną polityczną, i druga, stworzona i szerzona za pomocą znacznie skromniejszych środków przez przeciwników władzy komunistycznej.

Nawiasem mówiąc, uproszczony i stereotypowy obraz hiszpańskiej wojny domowej nie był charakterystyczny wyłącznie dla powojennej propagandy. Podobne spojrzenie zostało uwiecznione w powieści Jorgego Semprúna Wielka podróż, której bohater, uciekinier z ogarniętej wojną Hiszpanii, tak wspominał swoje zetknięcie z Francuzami: Wtaśnie w Bajonnie, na nadbrzeżu niedaleko rynku, dowiedziatem się, że jestem czerwonym Hiszpanem. Nazajutrz przeżytem druga niespodziankę, kiedy przeczytaliśmy w gazecie, że w Hiszpanii są czerwoni i nacjonaliści. Dlaczego to byli nacjonaliści, skoro walczyli wspólnie z wojskami marokańskimi, z legia cudzoziemska, z samolotami niemieckimi $i z$ dywizjami Littoria, trudno byto pojąc ${ }^{25}$.

Obie zaprezentowane w Madame wizje są czarno-białe, przedstawiają historię Hiszpanii lat 30. jako starcie dwóch skrajnych opcji światopoglądowych. Łączy je to, że Półwysep Iberyjski postrzegany jest jako teren walki potężnych sit, a jego mieszkańcy nie są podmiotem konfliktu, lecz narzędziem, którym te siły się posługują. Natomiast kogo innego obsadza się w rolach negatywnych bohaterów. Oba warianty są niewolne od obiegowych sądów i wyobrażeń, silnie zideologizowane, uwikłane w rodzime mitologie polityczne. W żadnym nie daje się dostrzec próby spojrzenia na tragedię Hiszpanii w sposób obiektywny, zdystansowania się od własnych przekonań i uwarunkowań. Nie chodzi w nich o poznanie historii wojny domowej czy podjęcie wysiłku zrozumienia tego, co i dlaczego się wydarzyło. Wszystko jest postrzegane przez pryzmat wielkiej polityki i w tych kategoriach objaśniane, tym samym uwarunkowania lokalne ulegają unieważnieniu. $\mathrm{Z}$ pola widzenia znikają bohaterowie wydarzeń, żywi ludzie, tragedie jednostek i społeczności, przestaje się dostrzegać cierpienie, traumę zarówno indywidualną, jak i pokoleniową. Pamięć hiszpańskiego konfliktu jest przez obie strony wykorzystywana po to, by wyeksponować swój własny punkt widzenia na światową politykę dawniejszą i współczesną ${ }^{26}$. W takich zabiegach trudno dostrzec choćby minimalny

24 Trudno mi się zgodzić ze stwierdzeniem Moniki Bednarczuk, że powieść Libery rozprawia się z zafatszowanym obrazem wojny. M. Bednarczuk, Obraz hiszpańskiej wojny domowej..., s. 283.

25 J. Semprún, Wielka podróż, przeł. K. Dolatowska, Warszawa 1964, s. 110.

26 Instrumentalne traktowanie kwestii wojny domowej w Hiszpanii przez wyznających różne doktryny uczestników dyskursu politycznego widać również w polskiej publicystyce politycznej. W podsumowaniu obszernej rozprawy poświęconej temu zagadnieniu czytamy: W każdym z opisywanych $i$ analizowanych reżimów ogólny cel dyskursu politycznego o wojnie domowej byt taki sam: użycie historii ( $w$ tym 
szacunek dla pamięci Innych, jest ona bowiem instrumentalizowana, służy jako źródło argumentów niezbędnych do uwiarygodnienia własnej wizji świata i historii. Tragedia Innych okazuje się niczym więcej, niż środkiem retorycznym służącym do manipulowania odbiorcami po to, by widzieli świat w sposób zgodny z optyką nadawcy. W ten sposób pamięć hiszpańskiej wojny domowej, poddana różnym interpretacjom ideologicznym, podlega znacznej deformacji.

Nie można jednak zapominać, że oba opisane tu warianty wyjaśniające genezę hiszpańskiego konfliktu pojawiają się w utworze artystycznym - w powieści, stanowią zatem elementy świata przedstawionego, a nie rzeczywistego. $\mathrm{Na}$ ich ostateczny kształt musiały wpłynąć co najmniej dwa filtry. Za jeden należy uznać osobistą pamięć autora, który w swym utworze przetwarza reminiscencje z czasów szkolnych. Drugim jest konwencja literacka, czyli sposób mówienia o świecie charakterystyczny dla prozy powieściowej. Obie wizje wojny domowej są przecież wzięte w ironiczny cudzysłów. Przebieg akademii ku czci rocznicy wybuchu wojny domowej ma charakter satyryczny, momentami nawet można się w nim dopatrzeć elementów parodii - choćby w postaci Lucylli Różogrodek, ucharakteryzowanej na Dolores Ibárruri. Trudno również brać na serio pełną sprzeczności interpretację wydarzeń na Półwyspie wygłaszaną w uniesieniu przez Konstantego, który, zapewne nieświadomie, powtarzał argumenty Falangi Hiszpańskiej (Falange Española). Wydaje się, że autora powieści nie interesowała hiszpańska wojna domowa jako taka, ani nawet to, co ludzie o niej myśleli i mówili. Przedmiotem jego refleksji był raczej sposób postrzegania dwudziestowiecznej historii i posługiwania się nią przez wyznawców różnych światopoglądów do obrony własnych racji. Wojna domowa stała się zatem elementem strategii narracyjnej, narzędziem literackim służącym do ukazania radykalnie odmiennych postaw ideologicznych, ścierających się w Polsce lat 60. XX wieku. Pamięć o hiszpańskim konflikcie, która w polskim kontekście znalazła się dzięki medium, jakie stanowi powieść, została w ten sposób całkowicie zawłaszczona i przetworzona.

Podróż pamięci, o której pisze Erll, niekoniecznie więc musi się jej przysłużyć. W opisywanym przypadku uwarunkowania lokalne okazały się na tyle silne, że treści będące przedmiotem pamięci zeszly na dalszy plan. W obcym kontekście pamięć o wydarzeniach z przeszłości podlega bowiem oddziaływaniu różnych czynników, w efekcie może ulec zniekształceniom. Ważniejsze może okazać się to, co miejscowe i bliskie, natomiast to, co dotyczy innych - mniej istotne. Pamięć dramatów będących udziałem ludzi zamieszkujących odległe obszary nie porusza nas tak, jak tragiczne wątki naszej własnej historii. Ponadto cudza pamięć przeniesiona z innego podłoża kulturowego jest bardziej podatna na różnego rodzaju manipulacje, bo zdemaskowanie takiego działania jest trudniejsze, ze względu na mniejszą wiedzę o historii innych krajów i brak przekazu międzypokoleniowego. Trauma innych nie musi wzbudzać naszych emocji, a pamięć o niej może być szanowana tylko pozornie, w rzeczywistości służąc strategiom retorycznym lub literackim.

manipulowanie historia) jako narzędzia stużacego realizacji interesu politycznego. W każdym z badanych okresów politycy dostrzegali konieczność zachowania zgodności między historia a ideologia (idea polityczna) [...]. W. Opioła, Hiszpańska wojna domowa w polskich dyskursach politycznych. Analiza publicystyki 1936-2015, Opole 2016, s. 255, Studia i Monografie, nr 531. 


\section{BIBLIOGRAFIA}

Bednarczuk M., Obraz hiszpańskiej wojny domowej lat 1936-1939 w piśmiennictwie polskim, Toruń 2008.

Erll A., Travelling Memory, „Parallax” 2011, vol. 17, nr 4.

Erll A., Wędrująca pamięć, przet. T. Kunz, [w:] Migracyjna pamięć, wspólnota, tożsamość, red. R. Sendyka, T. Sapota, R. Nycz, Warszawa 2016.

Hirsch M., Family Pictures. Maus, Mourning and Post-Memory, „Discourse” 1992/1993, vol. 15, nr 2.

Libera A., Madame, Kraków 2000.

Nalewajko M., Nieznani a bliscy. Historyczne i spoteczne uwarunkowania percepcji polskiej emigracji przetomu XX i XXI wieku w Hiszpanii, Warszawa 2012.

Opioła W., Hiszpañska wojna domowa w polskich dyskursach politycznych. Analiza publicystyki 1936-2015, Opole 2016, Studia i Monografie, nr 531.

Osiński Z., Nauczanie historii w szkotach podstawowych w Polsce w latach 1944-1989. Uwarunkowania organizacyjne oraz ideologiczno-polityczne, Poznań 2010.

Semprún J., Wielka podróż, przeł. K. Dolatowska, Warszawa 1964.

Valls Montés R., Historiografía escolar española: siglos XIX-XXI, Madrid 2012.

Żaryn M., Polityka historyczna w edukacji w PRL, [w:] Polityka czy propaganda. PRL wobec historii, red. P. Skibiński, T. Wiścicki, Warszawa 2009.

Dr hab. Małgorzata GASZYŃSKA-MAGIERA - iberystka, absolwentka Uniwersytetu Jagiellońskiego, aktualnie profesor Uniwersytetu Warszawskiego. Wykłada literaturę hiszpańską i hispanoamerykańską oraz translatorykę. Autorka monografii Granice przektadalności. Subjuntivo i jego polskie ekwiwalenty w ttumaczeniach prozy latynoamerykańskiej (1997) oraz Recepcja przektadów literatury iberoamerykańskiej w Polsce w latach 1945-2005 zperspektywy komunikacji międzykulturowej (2011), a także artykułów o przekładach literackich i ich recepcji. Jej obecne zainteresowania koncentrują się na związkach przekładu i pamięci. Inicjatorka cyklu konferencji „Oblicza postpamięci”. 